\title{
Eclectisch denken: enkele historische overwegingen
}

\author{
A. Goudriaan
}

\begin{abstract}
Starting from the assumption that education and scholarship are important venues for the transmission and preservation of culture, this article notes that non-Christian writings have had a significant and lasting impact throughout the history of learning in Western Christianity. It is then argued that eclecticism, the selective and critical usage of texts and ideas from various backgrounds, has been a deliberate practice in Christian history. As an expression of independent thinking, eclecticism allows the positive use of what a critical inquiry has shown to be "good" (1 Thess. 5:21) in nonChristian (and Christian) sources. When it succeeds in maintaining its critical independence and its commitment to truth, eclecticism does not produce what G.W.F. Hegel called "superficial aggregates".
\end{abstract}

\section{Gedomineerd door niet-christelijke cultuur?}

De geschiedenis van de vroege kerk laat duidelijke voorbeelden zien van christenen die radicaal afstand namen van religieuze opvattingen en praktijken die gangbaar waren in hun niet-christelijke omgeving. Keizerverering, gladiatorenspelen, en participatie in pagane religieuze praktijken zijn slechts enkele voorbeelden van wat christenen in de eerste eeuwen doorgaans afwezen. ${ }^{1}$ Tegelijk zijn tot op de dag van vandaag stemmen te beluisteren die zowel de periode van de vroege kerk alsook latere ontwikkelingen in de kerkgeschiedenis kritiseren vanwege juist een gebrek aan distantie ten opzichte van heersende tradities en omringende cultuur. De dogmenhistoricus Adolf von Harnack formuleerde zijn kritische visie op wat hij zag als de "hellenisering

1 Voor een klassiek en beknopt overzicht, zie Adolf von Harnack, Die Mission und Ausbreitung des Christentums in den ersten drei Jahrhunderten, deel 1 (vierde druk, 1924), Darmstadt 2018, 300-324. 
van het christendom". ${ }^{2}$ In de dertiende eeuw leverde de toenemende invloed van Aristoteles aan de universiteiten van Parijs en Oxford een reeks van officiële veroordelingen van aristotelische opvattingen op. ${ }^{3}$ Nog in de zestiende eeuw uitte Martin Luther onverbloemde kritiek op aristotelische invloeden in de theologie, vanuit de overtuiging dat "de hele Aristoteles zich verhoudt tot de theologie zoals duisternis tot licht."

Onderwijs en wetenschap zijn een centrale plaats waar cultuur wordt gevormd en doorgegeven, en tegelijk ook een terrein waarop door de eeuwen heen niet-christelijke inbreng sterk aanwezig is geweest. Weliswaar zijn er in de loop van de geschiedenis tal van voorbeelden te noemen van christelijk onderwijs. In de tweede eeuw gaf Justinus Martyr in Rome lessen aan belangstellenden. ${ }^{5}$ De school van Origenes in Caesarea is wel getypeerd als de "eerste ondubbelzinnig aangetoonde christelijke private universiteit". ${ }^{6}$ In het middeleeuwse Europa zijn onder christelijk voorteken universiteiten gesticht, en in de vroegmoderne tijd ontstonden ook onder reformatorische invloed nieuwe academies.

Toch is in het christelijke onderwijs en in de wetenschapsbeoefening de niet-christelijke cultuur opvallend sterk aanwezig geweest. In de tweede eeuw,

2 Zie o.a. E.P. Meijering, Die Hellenisierung des Christentums im Urteil Adolf von Harnacks, Amsterdam 1985. Harnack was de eerste noch de laatste die deze hellenisering aan de orde stelde, zie bijvoorbeeld Leo Scheffczyk, Tendenzen und Brennpunkte der neueren Problematik um die Hellenisierung des Christentums, München 1982; Adolf Martin Ritter, 'Ulrich Wickert, Wolfhart Pannenberg und das Problem der "Hellenisierung des Christentums"', in Barbara Aland e.a. (red.), Die Weltlichkeit des Glaubens in der Alten Kirche. Festschrift für Ulrich Wickert zum siebzigsten Geburtstag, Berlijn 1997, 303-318.

3 Voor Parijs, zie bijvoorbeeld J.M.M.H. Thijssen, Censure and Heresy at the University of Paris, 1200-1400, Philadelphia 1998; David Piché en Claude Lafleur, La condamnation Parisienne de 1277. Nouvelle édition du texte latin, traduction, introduction et commentaire, Parijs 1999; Roland Hissette, Enquête sur les 219 articles condamnés à Paris le 7 mars 1277, Parijs 1977.

4 Martin Luther, Disputatio contra scholasticam theologiam (1517), stelling 50, in: Erich Vogelsang (red.), Luthers Werke in Auswahl, 5, Berlijn 1955, 324: "Breviter, Totus Aristoteles ad theologiam est tenebrae ad lucem".

5 Zie Jörg Ulrich, 'What Do We Know about Justin's "School” in Rome', Zeitschrift für antikes Christentum, 16 (2012), 62-74; Tobias Georges, 'Justin's School in Rome-Reflections on Early Christian “Schools"', Zeitschrift für antikes Christentum, 16 (2012), 75-87.

6 Christoph Markschies, Kaiserzeitliche christliche Theologie und ihre Institutionen, Tübingen 2007, 102. Over het zeer innovatieve Hexapla-project dat Origenes in Caesarea tot uitvoering bracht, zie Anthony Grafton en Megan Williams, Christianity and the Transformation of the Book: Origen, Eusebius, and the Library of Caesarea, Cambridge MA, 2006. 
toen het christendom nog een ongeoorloofde religie was, was het curriculum in wat we lager en middelbaar onderwijs ${ }^{7}$ zouden kunnen noemen gestempeld door auteurs die hun heidens-religieuze opvattingen en conventies in hun werken tot uitdrukking brachten. Tertullianus zag de situatie als een zaak van overmacht: omdat christenen nu eenmaal niet op een andere manier onderwijs konden krijgen dan door zich te voegen naar de heersende canon, was het naar zijn mening geoorloofd om student te zijn, mits men de lessen volgde met een mentale reserve. Voor docenten was het een andere kwestie: wie over het standaardrepertoire van klassieke teksten onderwijs gaf, doceerde meteen ook in pagane godsdienstigheid, en dat was naar zijn overtuiging bepaald geen bezigheid die met het christelijke geloof te combineren viel. ${ }^{8}$ In soortgelijke trant valt in een derde-eeuwse kerkorde te lezen: "als iemand kleine kinderen onderwijst, is het goed daarmee te stoppen, maar als hij geen ander vak kent, is het hem toegestaan."9

Het idee dat de culturele niet-christelijke religieuze bagage in het onderwijs een situatie van overmacht inhield, was vrij algemeen verbreid. Christenen reageerden verschillend, maar "de meesten lijken niet bijzonder bezorgd te zijn geweest" 10 en over een streven naar alternatieven valt weinig te vernemen: de gedachte om christelijk onderwijs op te zetten wordt nooit of zelden uitgesproken, althans voor wat betreft het primaire en middelbare onderwijs, ${ }^{11}$ en ook de pogingen om christelijk lesmateriaal te schrijven, zijn relatief schaars gebleven. ${ }^{12}$ Christenen participeerden kennelijk in het

7 Er waren "three stages: primary (from age seven to eleven), secondary (from twelve to fifteen), and advanced (until about twenty)"; Everett Ferguson, 'Education', in idem e.a. (red.), Encyclopedia of Early Christianity, tweede druk, New York 1999, 361-362, daar 361.

8 Tertullianus, De idololatria, 10, in J.H. Waszink en J.C.M. van Winden (red.), Tertullianus, De idololatria. Critical tekst, Translation and Commentary, Leiden 1987, 38-41. Cf. Markschies, Theologie, 54-55 en voor een soortgelijke opvatting van Hiëronymus, zie H.I. Marrou, A History of Education in Antiquity, vert. George Lamb, Madison 1956, 321.

9 Traditio apostolica 16, geciteerd in Markschies, Kaiserzeitliche christliche Theologie, 55; Marrou, History of Education, 322; Harnack, Mission, deel 1, 300. Teksteditie met Duitse vertaling en annotatie van Wilhelm Geerlings, in Georg Schöllgen en Wilhelm Geerlings, Didache: Zwölf-Apostel-Lehre. Traditio Apostolica: Apostolische Überlieferung [Fontes Christiani 1], Freiburg 1991, 246.

10 Edward J. Watts, City and School in Late Antique Athens and Alexandria, Berkeley 2006, 19.

11 Marrou, A History of Education in Antiquity, 321, 326; cf. Wilhelm Krause, Die Stellung der frühchristlichen Autoren zur heidnischen Literatur, Wenen 1958, 105; Markschies, Kaiserzeitliche christliche Theologie, 54.

12 Markschies, Kaiserzeitliche christliche Theologie, 50-52, 70-75. 
onderwijssysteem zoals het voorhanden was. Opvallend is dat keizer Julianus (de Afvallige), toen hij in 362 het aan christenen verbood om leraar te zijn, schreef dat christenen over de boeken van "Homerus, Hesiodus, Demosthenes, Herodotus, Thycidides, Isocrates en Lysias" niet op een authentieke manier onderwijs konden geven. Kennelijk waren er christenen in het onderwijs werkzaam. ${ }^{13}$ Julianus' bezwaar was dat christenen die over heidense teksten lesgaven, dit deden zonder ook de godsdienstige inhoud voor hun rekening te nemen, dus integendeel met al dan niet uitgesproken distantie en reserve. Julianus wilde daar een eind aan maken: volgens hem was het "paradoxaal" om docenten onderwijs te laten geven over "zaken waarvan zij menen dat ze niet waar zijn". ${ }^{14}$ Intussen waren de door Julianus genoemde auteurs dus wel onderdeel van het standaardcurriculum gebleven, ook in de tijd sinds keizer Constantijn, toen het christendom eerst geoorloofde religie en later ook staatsreligie was geworden. Voor die persistentie van de klassieke canon zijn verschillende verklaringen gegeven. De beperkte christianisering van de christenen zelf is genoemd als gedeeltelijke verklaring; ${ }^{15}$ en de sociale dimensie van het onderwijs dat de maatschappelijke bovenlaag samenbond en een gemeenschappelijk referentiekader bood. ${ }^{16}$ Hoe dat ook zij, het ontbreken van een succesvol en omvattend christelijk alternatief voor de pagane canon is opvallend, maar het impliceert niet dat verzet en weerbaarheid, openlijk of impliciet, hebben ontbroken. Choricius van Gaza heeft niet als enige een eclectische houding bepleit: "uit de poëzie datgene kiezen wat nuttig is en intussen glimlachen over de mythen". ${ }^{17}$

In de Middeleeuwen was, bij het geleidelijk bekend worden van Aristoteles' geschriften in Latijnse vertaling, aanvankelijk de weerstand groot, zoals blijkt uit diverse veroordelingen van aristotelische opvattingen, niet in de laatste plaats aristotelische opvattingen zoals toentertijd door katholieken verdedigd werden aan de universiteiten van Parijs en Oxford. ${ }^{18}$ Maar Aristoteles won terrein en werd tot "de filosoof" zonder meer van de scholastiek, een auteur die op het begrippenapparaat en de denkvormen van de wetenschapsbeoefening inclusief de theologie grote invloed had.

13 Zie ook Markschies, Kaiserzeitliche christliche Theologie, 59.

14 P.R. Coleman-Norton, Roman State and Christian Church. A Collection of Legal Documents to A.D. 535, deel 1, Londen 1966, 277-280 (Julianus, Ep. 422A-4A).

15 Markschies, Kaiserzeitliche christliche Theologie, 53-54.

16 Watts, City and School, 14-15.

17 Choricius van Gaza, geciteerd door Watts, City and School, 20.

18 Zie boven, noot 2 . 
In de reformatietijd heeft ook de Academie van Genève, in 1559 gesticht onder Johannes Calvijn, zich allerminst van klassieke culturele invloeden willen zuiveren. De statuten van de universiteit bepaalden dat de hoogleraar Grieks in zijn lessen de wijsgerige ethiek moest doceren aan de hand van "een boek van Aristoteles, Plato of Plutarchus, of van een christelijke filosoof". ${ }^{19}$ Dat de christelijke filosoof als laatste optie genoemd wordt, na drie antiekheidense autoriteiten, suggereert dat althans in dit vakgebied het antiek-culturele erfgoed een zo vanzelfsprekende, gezaghebbende en nuttige bron van onderwijs werd gevonden, dat vervanging door christelijke literatuur geen urgentie had. Ook op andere punten van het Geneefse curriculum was de klassieke literatuur nadrukkelijk vertegenwoordigd: studenten moesten kennisnemen van een selectie uit auteurs zoals Aristoteles, Demosthenes, Homerus, Xenophon, Polybius, Herodianus, Vergilius, Titus Livius, Isocrates of Cicero. ${ }^{20}$

Heeft dus het pagane denken ook in christelijke kring het onderwijs gedomineerd? Hoe is de sterke presentie van niet-christelijke bronnen te begrijpen als passend bij een christelijk leven? De geschiedschrijving kent prominente voorbeelden van auteurs die de beïnvloeding van de theologie door het antiek-culturele en wijsgerige erfgoed als een vervalsing van het christendom hebben gezien. Zulke analyses kunnen in specifieke gevallen terecht zijn, maar als algemene evaluatieve strategie is de gedachte dat het christelijke denken gezuiverd had moeten worden van bredere culturele elementen niet goed houdbaar. Het christelijke denken is tot dusver zozeer verweven geweest met de antieke culturele erfenis, dat wie daar afstand van zou willen doen meteen ook afstand moet nemen van een groot deel van de traditie, inclusief de Reformatie, en zelfs van de bijbelse canon. ${ }^{21}$

19 L'Ordre du College de Geneve, Genève [1559], b4v-c1r: “... quelque liure de Philosophie qui concerne les meurs, le liure sera d'Aristote, ou Platon, ou Plutarque, ou de quelque philosophe Chrestien."

20 L'Ordre, b2r-v en c1r.

21 In Origenes' opvatting dat de apostel Paulus antieke auteurs zoals Aratus, Epimenides en Menander citeerde "om hen te heiligen (ut sanctificet ea)" ligt de dubbele veronderstelling besloten dat deze teksten tevoren niet geheiligd waren en dat het in principe mogelijk is om "ook woorden van hen die buiten zijn (verba etiam de his quae foris sunt)" toe te wijden aan de dienst van God (Harnack, Die Mission, deel 1, 316, citeert Hom. 31 over Lukas; zie Henri Crouzel et al. (red.), Origène, Homélies sur S. Luc: texte latin et fragments grecs. Introduction, traduction et notes [SC 87], Parijs 1962, 380-381, daar 380 (Hom. 31.3; mijn vertaling volgt Harnack die in plaats van "quae" (Crouzels tekst) leest: "qui”)). 
Een combinatie van kritische afwijzing en positieve verwerking lijkt vanaf de vroege kerk een gangbare werkwijze te zijn. ${ }^{22}$ Zo'n werkwijze stelt mensen in staat om ook met een voorgegeven curriculum kritisch om te gaan, en om overigens - zoals de apostel zegt, uiteenlopende zaken te onderzoeken en het goede te behouden (1Thes. 5:21). In het vervolg van dit artikel wil ik enkele voorbeelden noemen van deze eclectische werkwijze die positieve benutting combineert met kritische distantie of afwijzing. De 'katholiciteit' van cultureel eclecticisme is met zo'n beperkte reeks van voorbeelden niet strikt bewezen, maar de voorbeelden laten in elk geval zien dat, en in welke zin, er door de geschiedenis heen pleitbezorgers van eclectiek zijn geweest. Die constatering van een soort van 'rode draad'23 laat uiteraard onverlet dat elk van deze pleitbezorgers een eigen historische context en een eigen theologisch-wijsgerige oriëntatie heeft gehad, die ook met zeer uiteenlopende hermeneutieken verbonden kan zijn geweest.

\section{Eclectiek}

Lang niet in alle gevallen waarin feitelijk van een eclectische werkwijze sprake is, is het selectieve of eclectische element ook met zoveel woorden tot uitdrukking gebracht. Het woord "eclectisch" is weliswaar in christelijke literatuur al door Clemens van Alexandrië gebruikt, maar hetzelfde verschijnsel van kritische selectiviteit kan ook op andere manieren omschreven worden. ${ }^{24}$

22 Vergelijk bijvoorbeeld Michael Fiedrowicz, Apologie im frühen Christentum. Die Kontroverse um den christlichen Wahrheitsanspruch in den erste Jahrhunderten, derde druk, Paderborn 2000, 147-149; C.J. de Vogel onderscheidde een "synthetische" van een "antithetische" houding, Wijsgerige aspecten van het vroeg-christelijke denken. Kleine geschiedenis van de patristische en vroeg-middeleeuwse wijsbegeerte, Baarn 1970.

23 Het belang van historische aandacht voor relatief lange tijdsperioden is recent onder meer verdedigd door David Armitage, 'What's the Big Idea? Intellectual History and the Longue Durée', History of European Ideas 38 (2012), 493-507; Jo Guldi en David Armitage, The History Manifesto, Cambridge 2014.

24 Over eclectiek, zie Michael Albrecht, Eklektik. Eine Begriffsgeschichte mit Hinweisen auf die Philosophie- und Wissenschaftsgeschichte, Stuttgart 1993; verder idem, 'Eklektizismus II. Philosophiegeschichtlich', in: Hans Dieter Betz e.a. (red.), Religion in Geschichte und Gegenwart, vierde druk, deel 2, Tübingen 1999, 1184-1185; W. Nieke, 'Eklektizismus', in Joachim Ritter e.a. (red.), Historisches Wörterbuch der Philosophie, deel 2, Basel 1972, 432433; Horst Dreitzel, 'Zur Entwicklung und Eigenart der "eklektischen Philosophie", Zeitschrift für historische Forschung 18 (1991), 281-343. Martin Mulsow, 'Eclecticism or Skepticism? A Problem of the Early Enlightenment', Journal of the History of Ideas 58 (1997), 465-477. 
(a) Zo heeft Christian Gnilka een diepgaand onderzoek gedaan naar het begrip chrèsis, dat is 'gebruik' of 'juist gebruik', van antiek erfgoed bij de kerkvaders. ${ }^{25}$ Als iets voor bruikbaar geldt en iets anders niet, of als het 'rechte gebruik' onderscheiden wordt van het minder juiste gebruik, dan is in wezen dezelfde attitude aanwezig als die het woord 'eclectisch' aanduidt. (b) Ook wie zijn werkwijze typeert door te zeggen: "Plato is een vriend, Aristoteles is een vriend, maar een vriend is bovenal de waarheid", gaat op een kritisch-selectieve manier om met wat door belangrijke schrijvers is gezegd. ${ }^{26}$ In het Nederlandse gereformeerde protestantisme is die uitspraak geregeld terug te vinden, onder meer bij William Ames, Jacobus Koelman en in het Groningse oordeel van 1651 over de filosofie van Descartes. ${ }^{27}$ (c) Vanaf de vroege kerk gelden de zogenoemde spolia Aegyptiorum, de buit van de Egyptenaren, als analogie voor het gebruik van antiek erfgoed. Bij de uittocht uit Egypte namen de Israëlieten goud en zilver mee (Ex. 3:22). Volgens sommige kerkvaders kan die episode gelezen worden als allegorie voor een nieuwe gebruikmaking van het culturele erfgoed van heidenen. Deze vergelijking is eeuwen later in de

25 Christian Gnilka, Chrêsis. Die Methode der Kirchenväter im Umgang mit der antiken Kultur I: Der Begriff des rechten Gebrauchs, tweede uitgebreide druk, Basel 2012 (de tweede druk is inderdaad significant uitgebreid: de 151 pagina's van de eerste druk (1984) zijn er 376 geworden).

26 De uitdrukking komt in beginsel al in de Oudheid voor. Zie Hans-Georg Gadamer, 'Amicus Plato magis amica veritas', Gesammelte Werke, deel 6, Tübingen 1985, 71-89, hier 71. J. Koelman, Het vergift van de Cartesiaansche philosophie grondig ontdekt, Amsterdam 1692, 120, verwijst naar Ammonius' commentaar op de Categorieën van Aristoteles, dat wil zeggen: de biografie van Aristoteles die onder meer is afgedrukt in de Ammoniuseditie van Bartholomaeus Sylvanius en Gaston Sala (red.), Ammonii Hermeae in Praedicamenta Aristotelis commentarii, Parijs 1542, 3: het is niet vreemd als Aristoteles van Plato afstand neemt, "sunt enim ipsius Platonis verba, veritatem magis curare quam aliud quidquam oportere. Nimirum haec quoque ad verbum inquit, amicus quidem est Socrates, sed veritas amicissima, et alibi: paulum quidem Socratis habenda ratio est, veritatis vero quamplurimum."

27 William Ames, Philosophemata, Leiden 1643, ${ }^{\star} 2$. Koelman, Vergift, 120. De tekstuele variant die het Groningse oordeel van 1651 formuleerde, is afgedrukt in Josef Bohatec, Die cartesianische Scholastik in der Philosophie und reformierten Dogmatik des 17. Jahrhunderts, Leipzig 1912, 151-153, hier 152: "Amici nobis sunt Socrates, Plato, Aristoteles, Conimbricenses, Suaresius, Ramus, Cartesius, sed magis amica veritas. Haec non ex personis, sed personas ex illa aestimamus." 
protestantse traditie nog door iemand als Franciscus Turrettini gemaakt. ${ }^{28}$ Voorzover het hergebruik van de Egyptische schatten een moment van selectie en een inzet van oordeelskracht vraagt, is ook hier een element van eclecticisme geïmpliceerd. (d) Een andere gangbare analogie die een eclectische werkwijze aangeeft, is die van de bijen, die uit verschillende bloemen hun honing tevoorschijn halen. Volgens Gnilka, die het vroegchristelijke gebruik van deze analogie analyseerde, wijst de vergelijking met de bijen - die her en der nectar zoeken en honing produceren - op de bruikbaarheid van allerlei bloemen, op de mogelijkheid van een kritische keuze, en op het ontstaan van "een nieuwe eenheid". 29

Justinus de Martelaar, die in Rome christelijk onderwijs gaf - een aantal van zijn leerlingen stierf samen met hem de marteldood - nam naar eigen zeggen kennis van allerlei filosofieën. Ze hadden allemaal hun gebreken, en Justinus begreep zichzelf nadrukkelijk als een christelijke filosoof, ${ }^{30}$ maar ze hadden blijkbaar ook hier en daar hun juiste inzichten. In zijn Tweede apologie schrijft Justinus over de Logos (rede; woord; Woord, dat is Christus) waarvan de zaden onder alle mensen verspreid zijn, zodat hij kon betogen: al wat onder de mensen aan waarheid te vinden is, is het eigendom van ons christenen. ${ }^{31}$ Deze uitspraak zou op het eerste gehoor imperialistisch kunnen klinken, maar is het logische gevolg van de visie dat alle mensen deelhebben aan de Logos, en dat is, zoals Justinus hier ook zegt (13.4), uiteindelijk Christus, en voorzover "alle schrijvers" het "ingeplante zaad van de Logos" in zich hebben, kunnen zij waarheid naar voren brengen (13.5), en bijvoorbeeld ook rechtvaardige wetten uitvaardigen. Tegelijk is die participatie van de mensen aan de Logos een partiële, dat wil zeggen: ze komt met gebreken - gebreken die voor iedereen duidelijk zichtbaar zijn in de eclatante contradicties van

28 Gnilka, Der Begriff des rechten Gebrauchs, index s.v. Ägypter; E.P. Meijering, Reformierte Scholastik und patristische Theologie. Die Bedeutung des Väterbeweises in der Institutio theologiae elencticae F. Turrettins, unter besonderer Berücksichtigung der Gotteslehre und Christologie, Nieuwkoop 1991, 39, 87-88; idem, Calvin wider die Neugierde. Ein Beitrag zum Vergleich zwischen reformatorischem und patristischem Denken, Nieuwkoop 1980, 67-69, 103.

29 Gnilka, Der Begriff des rechten Gebrauchs, 177-213, hier 177.

30 Zie bijvoorbeeld J.C.M. van Winden, An Early Christian Philosopher. Justin Martyr's Dialogue with Trypho, Chapters one to nine, Leiden 1971.

31 Justinus Martyr, Tweede apologie, 13.4; in Charles Munier (red.), Justin, Apologie pour les chrétiens. Introduction, texte critique, traduction et notes, Parijs 2006, 362-364. Voor meer commentaar, zie Charles Munier, Justin Martyr, Apologie pour les chrétiens. Introduction, traduction et commentaire, Parijs 2006, 338-339. 
filosofieën, intern en onderling. Die contradicties indiceren een onderneming die niet geslaagd mag heten. Justinus' visie kan eclectisch genoemd worden: hij accepteert wat waarheid is, en deze waarheid kan zich manifesteren in allerlei menselijke activiteit en denkwerk.

Clemens van Alexandrië heeft in zijn Stromata zich expliciet uitgesproken over wat hij noemde "eclectische filosofie"- waarmee hij, voor zover nu bekend is, de tweede auteur was die het woord 'eclectisch' als adjectief gebruikte om een denkrichting te benoemen. ${ }^{32}$ In hoofdstuk 7 van boek 1 beschrijft Clemens dat de Griekse beschaving goede elementen bevat die God aan de mensen gegeven heeft, waaronder de wijsbegeerte. God laat het op allerlei plaatsen regenen, zodat daar uiteenlopende gewassen kunnen groeien - al groeien ze niet overal even goed. Over de filosofie schrijft Clemens dan, hier in de oude Nederlandse vertaling van H.U. Meyboom:

Doch wijsbegeerte - $\mathrm{ik}$ bedoel niet de Stoïcijnsche, noch de Platonische of de Epicureesche en de Aristotelische, maar al wat bij elk dezer secten voortreffelijk gezegd is en met vrome wetenschap ten volle onderricht geeft in gerechtigheid - al dat uitgelezene noem ik wijsbegeerte. Daarentegen zou ik niet gaarne al de menschelijke redeneeringen, die men uitgesneden en bedrieglijk gestempeld heeft, goddelijk noemen. ${ }^{33}$

"Eclectische filosofie" noemde Clemens datgene wat door verschillende wijsgerige scholen "goed gezegd" is. De contradicties tussen de filosofenscholen golden in de vroege kerk meestal - met uitzondering misschien van Origenes die althans in de diversiteit van scholen geen principieel bezwaar zag ${ }^{34}-$ als een probleem, een indicatie van het falen van de wijsbegeerte. ${ }^{35}$ Als "goed"

32 Zie Albrecht, Eklektik, 79-90, daar 79 over Clemens als "nach Potamon [von Alexandrien] als der zweite uns überlieferte Autor, der dieses etwas ausgefallene Wort verwendet".

33 H.U. Meyboom (vert.), Clemens Alexandrinus V, Vlechtwerken I [Oud-christelijke geschriften in Nederlandsche vertaling 12], Leiden 1914, 41-42. Griekse tekst, Franse vertaling en annotatie in Claude Montdésert (red.), Clément d'Alexandrie, Les Stromates. Stromate I [SC 30], Parijs 1951, 74-75.

34 Vgl. Origenes, Contra Celsum, 3.10-13 en 5.61; Henry Chadwick, Origen, Contra Celsum. Translated, with an Introduction and Notes, Cambridge 2003, 134-136 en 311, daar 135 (3.12): " ... any teaching which has had a serious origin, and is beneficial to life, has caused different sects."

35 Een opmerkelijk voorbeeld is Hermias' satire over de Griekse filosofen: R.P.C. Hanson en Denise Joussot (red.), Hermias, Satire des philosophes païens. Introduction, texte critique, notes, appendices et index ... [et] traduction française [SC 388], Parijs 1993. 
gold voor Clemens wat "rechtvaardigheid leert met vrome kennis". Niet één school heeft de waarheid in pacht; die is op allerlei plaatsen te vinden, herkenbaar, vanuit christelijk gezichtspunt, aan vrome kennis, rechtvaardigheid, goedheid. ${ }^{36}$

Ook Origenes gaf onderwijs over een brede verzameling van teksten, zoals we weten uit het getuigenis van zijn leerling Gregorius de Wonderdoener (ca. 210-ca. 270). In zijn lofrede op Origenes beschrijft hij dat deze zijn leerlingen de opdracht gaf kennis te nemen van "alle geschriften van de oude filosofen en dichters", zonder op voorhand bepaalde boeken buiten beschouwing te laten of een oordeel te vellen. Uitzondering waren geschriften waarin het bestaan van God, of zijn voorzienigheid, ontkend werden - teksten van epicureëers dus. Gregorius benadrukt dat overigens het hele spectrum van literatuur bestudeerd moest worden zonder op voorhand iets af te wijzen of een evidente voorkeur te laten gelden. ${ }^{37}$ Wat de wijsbegeerte betreft, ging Origenes zo te werk dat hij zijn studenten niet vroeg één exclusief denksysteem te volgen. Integendeel wat in "elke filosoof bruikbaar" was, wilde hij erkennen, maar onwaarheid en pseudoreligie verwerpen. Hij gaf zijn studenten de raad om alleen op God en profeten te bouwen, niet op mensen, hoe erudiet of gerespecteerd ook. ${ }^{38}$

In de vroegmoderne tijd heeft ook de gereformeerde theologie vaak een eclectische benadering van de filosofie voorgestaan. ${ }^{39}$ Johannes Calvijn schreef bij Paulus' Epimenides-citaat in Titus 1:12 dat wij de waarheid te aanvaarden hebben, ook als deze door niet-godvrezenden wordt uitgesproken, aangezien de waarheid van God afkomstig is. ${ }^{40}$ In het Nederlandse

36 Over diverse interpretaties, zie Albrecht, Eklektik, 79-85. Vgl. Henry Chadwick, Early Christian Thought and the Classical Tradition. Studies in Justin, Clement, and Origen, Oxford 2002, 40-41.

37 Gregorius Thaumaturgus, Oratio prosphonetica ac panegyrica in Origenem, 151-153, in: Peter Guyot en Richard Klein (red.), Gregor der Wundertäter, Oratio prosphonetica ac panegyrica in Origenem [Fontes Christiani, 24], Freiburg 1996, 184-187.

38 Gregorius, Oratio, 170-173, in Guyot en Klein (red.), Gregor der Wundertäter, 194-197.

39 Zie onder meer Richard A. Muller, 'Reformation, Orthodoxy, "Christian Aristotelianism," and the Eclecticism of Early Modern Philosophy', Nederlands Archief voor Kerkgeschiedenis 81 (2001), 306-325; idem, Post-Reformation Reformed Dogmatics, deel 1, Grand Rapids 2003, 360-382; David S. Sytsma, Richard Baxter and the Mechanical Philosophers, New York 2017; Paul Helm, Human Nature from Calvin to Edwards, Grand Rapids 2018; Aza Goudriaan, Reformed Orthodoxy and Philosophy, 1625-1750, Leiden 2006, m.n. 35-36, 54-55.

40 Calvijn, Commentaar op Titus 1:12, geciteerd in Charles Partee, Calvin and Classical Philosophy, Leiden 1977, 147. 
gereformeerde protestantisme van de zeventiende eeuw is dezelfde attitude aan te treffen, zoals enkele voorbeelden kunnen laten zien.

In zijn disputatie over "bijbelse filosofie (philosophia sacra)" uit 1651 wierp Gisbertus Voetius de vraag op welke filosofie vanuit theologisch gezichtspunt het beste was. Hier is zijn uitvoerige antwoord, in de Nederlandse vertaling van Cornelis de Niet:

Conclusie 1: Van geen enkele stroming uit oude of nieuwe tijd mogen we de filosofie hetzij naar inhoud, hetzij naar vorm onvoorwaardelijk overnemen, laat staan dat we zouden mogen zweren bij de uitspraken van enig mens, zoals dit door sommigen steeds weer smadelijk ten laste gelegd wordt aan filosofen en theologen van hogescholen in de christenheid, en met name wel aan de gereformeerde christenheid, die graag zouden zien dat alle mensen toegebracht zouden worden tot de schare aanhangers van hun sprookjesleer (die ze zelf nog niet eens doorgronden en waarvan ze ook niet kunnen zeggen wat die nu eigenlijk is of moet gaan voorstellen).

Conclusie 2: Aan alle stromingen en filosofen mag het beste en meest zekere of zelfs (wanneer men niet verder gaan kan) het meest waarschijnlijke ontleend worden. Dit mag men ook zo zorgvuldig mogelijk in de eigen werkwijze opnemen en op een goede manier aan de christelijke theologie aanpassen.

Conclusie 3: Omdat dit het geval is bij de scholastieke filosofie volgens het stramien van de peripatetische filosofie zoals die in de christelijke, althans gereformeerde scholen over het algemeen onderwezen wordt (want voor zover ik weet wordt nergens de zuivere aristotelische filosofie gedoceerd, zonder enige bijmenging of interpolatie wat de inhoud of de vorm betreft), is de conclusie dat deze volstrekt de voorkeur verdient boven de oude filosofieën van Plato, de Stoa, Epicurus, zowel in hun theoretische, met name de metafysische aspecten, als in praktisch opzicht en boven de jongere wijsbegeerte van Ramus, Taurellus, Hermes of Paracelsus en de nieuwe sceptisch-epicureïsche of quasi-epicureïsche filosofie -

$1^{e}$ omdat zij algemene beginselen en uitgangspunten van het licht der natuur en de rechte rede behelst, die nooit ontkracht kunnen worden;

$2^{e}$ omdat zij zich goed leent voor een werkwijze met onderverdelingen, definities en argumententaties;

$3^{e}$ omdat zij het meest afgestemd is op de filosofische aangelegenheden zoals die hier en daar in de Schriften voorkomen, en onze theologie het beste dient;

$4^{e}$ omdat zij gericht is op het lezen en verstaan van geschriften van orthodoxe theologen en scholastieke schrijvers (waar die op een goede wijze theologiseren); 
$5^{e}$ omdat ze een heel geschikte blokkade vormt voor hedendaagse afwijkende leerstellingen en ketterijen ... en met behulp van haar methode, principes, axioma's en hypothesen het christelijke geloof op een volkomen veilige manier tegen godloochenaars, geestdrijvers, socinianen en andere ketters te verdedigen. Om deze redenen willen wij haar dan ook graag aanbevelen bij ijveraars voor het geloof en bij studenten in de theologie. ${ }^{41}$

Voetius' eerste twee conclusies brengen de zelfstandigheid van de eclecticus tot uitdrukking: hij levert zich aan geen concrete auteur of denkrichting uit, maar voegt wat als goed of zeker of waarschijnlijk beoordeeld wordt in het eigen denken in. De derde conclusie betoogt de relatief grotere bruikbaarheid van de aristotelische wijsbegeerte in vergelijking tot andere stromingen. Deze geschiktheid is voor Voetius een kwestie van inhoudelijke juistheid - overeenstemming met de natuur en de Schrift - ambachtelijke bruikbaarheid, de pedagogische behulpzaamheid om een denktraditie te ontsluiten, en de polemisch-theologische bruikbaarheid. De derde conclusie benoemt zo ook criteria die de kritische keuze van de eclecticus sturen.

De zeventiende-eeuwse theoloog Jacobus Koelman gaf in zijn boek over Het vergift der Cartesiaansche philosophie uit 1692 een beschouwing over de filosofie in het algemeen en de wijsgerige scholen uit de Oudheid. Naast de filosofieën van Plato en Aristoteles onderscheidde hij nog een tiental andere antieke stromingen binnen de Griekse filosofie, waarvan de tiende de "eclectische" filosofie was. ${ }^{42}$ Koelman vertelt dat Potamon van Alexandrië, volgens het bericht van Diogenes Laërtius, de stichter is van deze richting die zich niet slaafs aan één van de bestaande richtingen binden wilde. Uit het tijdperk van de vroege kerk noemt hij Clemens van Alexandrië en Origenes als representanten van deze richting die zich niet aan Plato of Aristoteles, maar aan de waarheid gebonden achtte. Koelman concludeert dat dit standpunt

41 Aza Goudriaan en Cornelis A. de Niet, 'Gisbertus Voetius' Introductio ad philosophiam sacram, Geschiedenis van de wijsbegeerte in Nederland 14 (2003), 25-56, hier 55. Gisbertus Voetius, Introductio ad philosophiam sacram [Daniel Suavius, 7 juli 1651], Utrecht 1651, C2r-C2v; later in licht gewijzigde vorm opgenomen in Gisbertus Voetius, Diatribae de theologia, philologia, historia et philosophia sacra, Utrecht 1668, 110-134, hier 132-133.

42 Jacobus Koelman, Het vergift van de cartesiaansche philosophie grondig ontdeckt, Amsterdam 1692. Over Koelman (1632-1695) en de filosofie, zie Theo Verbeek, 'Jacobus Koelman en de filosofie zijner dagen', Documentatieblad Nadere Reformatie 20 (1996), 62-71; Jacob van Sluis, 'Koelman, Jacobus (1632-1695)', in Wiep van Bunge e.a. (red.), Dictionary of Seventeenth- and Eighteenth-Century Dutch Philosophers, Bristol 2003, 567-568. 
overeenkomt met de oproep van Paulus om "alle dingen te beproeven en het goede te behouden" (1 Thes. 5:21). ${ }^{43}$ Koelman oordeelde zeer kritisch over de invloed van de wijsbegeerte op de theologie, vanaf de late Oudheid tot en met de Middeleeuwen. ${ }^{44}$ Maar "met de Reformatie der Religie" in de zestiende eeuw "is er ook een Reformatie in de Philosophie gekomen, en de misbruycken van de Aristotelische Philosophie zijn wech-genoomen". ${ }^{45} \mathrm{De}$ onderwijspolitieke vraag welke filosofie op universiteiten onderwezen zou moeten worden, beantwoordde Koelman in beginsel door aan te sluiten op de zestiende-eeuwse Reformatie die, na zuivering van de aristotelische wijsbegeerte, deze gemodificeerde wijsbegeerte liet onderwijzen. ${ }^{46} \mathrm{Hij}$ noemde bovendien nog een aantal aanvullende overwegingen ten gunste van de filosofie van Aristoteles, maar wilde niet het misverstand wekken als zou men "slaafachtig aan hem gebonden" zijn. Integendeel mocht of moest men "verder gaan in de kennis der wetenschappen, dan Aristoteles gekomen is". ${ }^{47}$ Koelman achtte zich dus aan Aristoteles geenszins gebonden, maar wilde zich aansluiten bij "de tiende boven genoemde Secte, de Elective, of verkiezende, om 't geen ons uit alles best aanstaat te omhelzen". Koelman citeerde zijn leermeester Johannes Hoornbeek, die eveneens voor deze eclectische filosofie gepleit had. ${ }^{48}$

Opvallend aan de positie van Hoornbeek was dat hij de eclectische benadering niet alleen als de beste maar ook als de modernste wijsgerige positie typeerde. In zijn Irenicum van 1688 had Hoornbeek drie belangrijke filosofische stromingen onderscheiden: "de oude, nieuwe, en nieuwste: De oude, aristotelische; de nieuwe, cartesiaanse; de nieuwste, eclectische". ${ }^{49}$ De indeling had vermoedelijk een wetenschapspolitieke bedoeling: het streven om de eclectische benadering de filosofie van heden en toekomst te doen zijn en

43 Koelman, Vergift, 119-120.

44 Koelman, Vergift, 121-141.

45 Koelman, Vergift, 141.

46 Koelman, Vergift, 141-142.

47 Koelman, Vergift, 144-145. Inspanningen van geleerden in het gereformeerde Europa hebben ertoe geleid, "dat nu de Philosophie in alle haar deele vry verder geavanceert is danze oit was ten tijde van Plato of Aristoteles" (146).

48 Koelman, Vergift, 145 en 146 (de hierboven geciteerde passages van Koelman), 146-148 (citaten van Koelman uit Hoornbeek, Irenicum en Oratio de prudentia).

49 Johannes Hoornbeek, Irenicum sive de studio pacis et concordiae. Addita est ejusdem oratio de prudentia, Utrecht 1688, 33: "Philosophorum triplex vulgo secta est, vetus, nova, novissima. Vetus, Aristotelica; Nova, Cartesiana; Novissima, Eclectica." 
blijven. Daarbij wilde Hoornbeek niet simpelweg bruikbare onderdelen uit het gechristianiseerde aristotelisme ${ }^{50}$ behouden en tegelijk ongewenste cartesiaanse innovaties uit de buurt houden. Veeleer werd Hoornbeek inhoudelijk gemotiveerd door de overtuiging dat het, hoe dan ook, wenselijk was om vrij en zelfstandig te denken en te oordelen. De eclectische wijsbegeerte bond zich niet slaafs aan auteurs en filosofische autoriteiten - zoals Hoornbeek bij cartesianen niet minder dan bij aristotelici had zien gebeuren - maar aan het beste inzicht. Die benadering stemde overeen met de apostolische aanbeveling om alles te onderzoeken en het goede te behouden (1 Thes. 5:21). De eclectische richting was, concludeerde Hoornbeek, "de oudste, de meest algemene, en ten slotte de meest vrije manier van filosoferen" ${ }^{51}$ Het was een aanpak die zich richtte op de filosofie zelf, niet op de namen van filosofen. ${ }^{52}$

Dat laatste punt had Hoornbeek in 1665 ook in zijn rede over prudentie al gemaakt:

het behoort tot de voorzichtigheid om uit alle [auteurs] de beste zaken te kiezen, om zaken die daarbij passen als nieuw toe te voegen, om niet de auteurs maar de natuur te volgen, te onderzoeken, uit te leggen ... ${ }^{53}$

De filosofen waren nu eenmaal al eeuwenlang verdeeld in hun opvattingen, en zo was ook steeds die werkwijze het meest prudent geweest "die door de ouden eclectisch is genoemd", en die feitelijk in lijn is met de apostolische oproep om 'alles te onderzoeken en het goede te behouden' (1 Thes. 5:21). ${ }^{54}$ Hoornbeek was er zeer van overtuigd dat eclecticisme een expressie is van vrijheid, zelfstandigheid, ware filosofie. Wie zich vastlegt op de opvatting van

50 Over de (christelijke en gereformeerde) aanpassingen: Hoornbeek, Irenicum, 33-34.

51 Hoornbeek, Irenicum, 35: "Certe idem in suis singuli philosophiis fecerunt Autores, in veteri, et in nova; atque iste philosophandi modus antiquissimus, et communissimus est, denique liberrimus." Voor de verwijzing naar 1 Thes. 5:21, zie ibid.

52 Hoornbeek, Irenicum, 35, stelt aan cartesianen de vraag: "an ex auctoribus, quicunque ii demum sint, docenda sit philosophia, an non potius ex sola rerum natura." Bij de beschrijving van de eclectische wijsbegeerte: "Non philosophia ex philosophis formanda, sed ex philosophia sunt formandi philosophi." Voor de onderscheiding tussen "namen van filosofen" enerzijds en "de filosofie" zelf anderzijds, zie ook de Oratio de prudentia, gehouden in Leiden op 8 februari 1665, in Irenicum, 72.

53 Hoornbeek, Oratio de prudentia, in Irenicum, 72: "prudentiae est, ex omnibus optima seligere, iis consimilia de novo addere, non auctores, sed naturam sequi, indagari, exponere ..."

54 Hoornbeek, Oratio de prudentia, 72. 
een gezaghebbende auteur "is inderdaad nog steeds een interpreet, maar niet een filosoof". Het gaat de ware filosoof immers "om de zaken, niet de woorden; om argumenten, niet postulaten". ${ }^{5}$

\section{Bruikbaarheid}

De zelfbewustheid van het door Hoornbeek en anderen bepleite eclecticisme als een vrije onderneming van zelfstandige en systematische denkers strookt niet met de reputatie die 'eclecticisme' soms heeft, als zou het gaan om gedachtenloos bloemen plukken die in een incoherent boeket belanden. Deze reputatie staat niet geheel los van de kritiek die filosofen zoals G.W.F. Hegel hebben geuit in de tijd van het Duitse idealisme - een kritiek op de eclectiek die in feite, zoals Michael Albrecht betoogt, "de oorspronkelijke intentie in het tegendeel verkeert” omdat de eclectiek aanvankelijk juist door kritische analyse de coherentie van de waarheid zocht. ${ }^{56}$

Hegel heeft in zijn Vorlesungen über die Geschichte der Philosophie, toen hij te spreken kwam op de alexandrijnse school die in de geschiedschrijving als eclectisch te boek staat, onderscheid gemaakt tussen een triviale en een diepere betekenis van het begrip eclecticisme. Volgens de triviale betekenis leverde eclecticisme een "oppervlakkig aggregaat (ein oberflächliches Aggregat)" op, terwijl eclecticisme volgens Hegels diepere betekenis het streven was om de eenzijdigheid van afzonderlijke principes te verenigen tot een dieper inzicht. Maar van de connotatie van "Herauslesen", zomaar uitzoeken, kwam het begrip volgens Hegel niet los; hij vond het niet goed bruikbaar. ${ }^{57}$

Men kan het risico van onsamenhangendheid en willekeur net als Hegel willen vermijden, zonder meteen te hoeven toegeven dat deze nadelen met de eclectiek als zodanig gegeven zijn. In de eerdere theologische begripsgeschiedenis is het begrip juist gerelateerd aan, onder meer, het goede - wellicht onder invloed van Paulus (1 Thes. 5:21) - aan waarheid en aan de zaak zelf in plaats van aan de meningen van vermeende autoriteiten daarover. De normativiteit van de christelijke eclectiek is vooral theologisch van aard geweest,

55 Hoornbeek, Oratio de prudentia, 73: "Qui enim alicujus sententiae se adstringit, hactenus interpres quidem est, non autem philosophus: qui etiam auctoritati alterius se mancipat, hic ne quidem esse philosophus unquam potest. Ille enim rebus intendit, non verbis; argumentis, non postulatis ..."

56 Michael Albrecht, 'Eklektizismus II', 1185.

57 Pierre Garniron en Walter Jaeschke (red.), Georg Wilhelm Friedrich Hegel, Vorlesungen über die Geschichte der Philosophie, dl. 3, Griechische Philosophie II. Plato bis Proklos, Hamburg 1996, 175, met commentaar op 439-440. Albrecht, Eklektik, 614-616. 
impliciet of expliciet gebonden aan de bijbelse canon. In Voetius' pleidooi voor selectieve gebruikmaking van het aristotelisme kwamen ook andere overwegingen naar voren. Hoe dat ook zij: zolang de eclectiek haar kritische onafhankelijkheid handhaaft, en haar gebondenheid aan waarheid, wordt ze niet getroffen door Hegels kritiek dat eclectiek als zodanig een "oppervlakkig aggregaat" zou opleveren. Bovendien kan het kritische ferment ervan bijdragen aan het bewaren van een christelijke levenshouding in een omgeving waarin niet-christelijke culturele producten een sterke presentie hebben.

A. Goudriaan is universitair hoofddocent historische theologie aan de Vrije Universiteit in Amsterdam. 